\title{
PENGARUH PENGGANTIAN DEDAK HALUS DENGAN KULIT KOPI TERHADAP PERSENTASE KARKAS DAN LEMAK ABDOMEN BROILER
}

\author{
Febriana F. Tatilu* , F.N. Sompie ${ }^{* *}$, Meity Imbar ${ }^{* *}$ Y.H.S. Kowel ${ }^{* *}$ \\ Fakultas Peternakan Universitas Sam Ratulangi, Manado 95115
}

\begin{abstract}
ABSTRAK
Penelitian ini bertujuan untuk mengetahui pengaruh penggantian dedak halus dengan kulit kopi terhadap persentase karkas dengan menggunakan 60 ekor broiler unsex strain Hubbard yang ditempatkan ke dalam 20 unit kandang yang telah dilaksanakan di Fakultas Peternakan. Penelitian ini dilakukan secara eksperimen menggunakan Rancangan Acak Lengkap yang terdiri atas 4 perlakuan dan 5 ulangan. Ransum perlakuan terdiri atas R0 (0\% kulit kopi), R1 (7\% kulit kopi), R2 (14\% kulit kopi), R3 (21\% kulit kopi). Variabel yang diukur dalam penelitian ini adalah persentase karkas dan persentase lemak adomen. Hasil analisis keragaman menunjukkan bahwa perlakuan memberikan pengaruh yang berbeda sangat nyata $(\mathrm{P}<0,01)$ terhadap persentase karkas dan persentase lemak abdomen. Hasil uji lanjut dengan uji beda nyata jujur (BNJ) menunjukkan bahwa tidak ada perbedaan yang nyata pada persentase karkas antara R0 $(72,77 \%)$, R1 $(71,96)$ dan R2 $(71,45 \%)$, tetapi pada R3 $(67,41 \%)$ persentase karkas nyata lebih rendah dibanding R1, R2 dan R3. Hasil uji BNJ untuk persentase lemak abdomen menunjukkan bahwa tidak ada perbedaan yang nyata antara R0 (1,78\%) dan R1 (1,7\%), tetapi nyata lebih tinggi dibanding R2 $(1,15 \%)$ dan R3 $(0,88 \%)$, sedangkan R2 nyata lebih tinggi dibandingkan R3. Berdasarkan hasil penelitian ini dapat disimpulkan bahwa penggantian dedak halus dengan kulit kopi sebanyak 14\% memberikan nilai persentase karkas dan lemak abdomen yang terbaik.
\end{abstract}

Kata Kunci : kulit kopi, broiler, persentase karkas, persentase lemak

\footnotetext{
* Alumni

** Jurusan Nutrisi dan Makanan Ternak
}

\begin{abstract}
THE EFFECTS OF SUBSTITUTION OF RICE BRAIN WITH COFFEE PULP ON BROILER'S CARCASS AND ABDOMINAL LIPID PERCENTAGES. A research evaluating the effects of substitution of rice brain with coffee pulp on broiler's carcass and abdominal lipid percentage has been conducted at Faculty of Animal Science. Sixty unsexed broiler's strain Hubbard were used in this experiment. The chicks were allocated into 20 units of cages. A Completely Randomized Design (CRD) was used with 4 treatments and 5 replications. The treatments were R0 ( $0 \%$ coffee pulp), R1 (7\% coffee pulp), R2 (14\% coffee pulp) and R3 ( $21 \%$ coffee pulp). Variable measure were : carcass percentage and abdominal lipid percentage. Anova showed that there were higly significant effects of treatment on carcass and abdominal lipid percentages. Honestly Significant Difference (HSD) test showed that there were no significant difference on carcass percentage among R0 (72.77\%), R1 (71.96\%), and R2 (71.45\%), however percentage carcass of R3 $(67.41 \%)$ significantly lower compared to R0, R1, and R2. There were no significant difference abdominal lipid percentage of R0 (1.78\%) and R1 (1.70\%). R0 and R1 were significantly higher compared to R2 (1.15\%) and R3 $(0.88 \%)$, however R2 was significantly higher compared to R3. It is concluded that the substitution of rice brain with $14 \%$ coffee pulp was the best effects on carcass and abdominal lipids of broiler.
\end{abstract}

Keyword : coffee pulp, broiler, carcass percentages, abdominal lipid. 


\section{PENDAHULUAN}

Meningkatnya selektivitas konsumen dalam memilih produk peternakan khususnya daging, menuntut peternak untuk dapat menghasilkan karkas dengan kandungan lemak yang rendah. Kualitas karkas dipengaruhi oleh beberapa faktor, antara lain ransum yang dikonsumsi broiler. Pemberian ransum dengan kandungan serat kasar yang tinggi merupakan salah satu cara yang dapat dilakukan guna mencegah terjadinya penimbunan lemak. Dedak halus merupakan salah satu bahan makanan yang dapat digunakan oleh peternak sebagai penyusun ransum broiler, akan tetapi memiliki beberapa kelemahan yakni harga yang tidak stabil karena ketersediaannya tergantung dari waktu panen padi (Anggorodi, 1985). Dedak halus juga memiliki kadar lemak yang tinggi (1418\%), sehingga sering mengalami ketengikan dalam penyimpanan disebabkan oleh adanya enzim lipolitik yang menjadi aktif ketika dedak berpisah dari beras dan dengan cepat meningkatkan kandungan asam-asam lemak bebas (Sukria dan Krisnan, 2009).

Aneka bahan atau limbah yang belum dimanfaatkan misalnya kulit buah kopi dapat menjadi bahan pakan alternatif sumber serat kasar melihat kandungannya dalam kulit buah kopi yakni 20,02\% (Hasil Analisis Bahan Kering Laboratorium Nutrisi Ternak Ruminansia dan Kimia Makanan Ternak, Fakultas Peternakan Universitas Padjajaran, 2014). Kulit buah kopi merupakan salah satu limbah dari agro industri dengan buah kopi sebagai bahan bakunya. Umumnya industri kopi hanya memanfaatkan kulit kopi sebagai kompos atau dibuang begitu saja, sehingga menjadi tumpukan sampah yang pada akhirnya merusak lingkungan. Sulawesi Utara khususnya Bolaang Mongondow yang merupakan sentra perkebunan kopi memiliki luas perkebunan 4.009,07 ha, dengan produksi kopi mencapai 2.135,46 ton bahan mentah yang belum dipisahkan antara buah kopi dengan daun dan batangnya. Setelah dipisah menghasilkan buah kopi sebanyak 1.281,22 ton per tahun. Dari pemisahan buah kopi antara biji dengan kulitnya, diperoleh kulit buah kopi sebanyak 448,449 ton (Dinas Perkebunan Sulawesi Utara, 2012).

Penelitian tentang penggunaan kulit buah kopi sebagai salah satu bahan pakan alternatif penyusun ransum sudah banyak dilakukan pada ternak ruminansia akan tetapi pada ternak monogastrik seperti broiler belum banyak dilakukan. Penelitian sebelumnya menyatakan bahwa dedak halus hingga $15 \%$ pada broiler jantan periode finisher dapat digantikan 
oleh kulit kopi, walaupun ada kecenderungan menurunnya konsumsi ransum, pertambahan berat badan, efisiensi penggunaan makanan dan persentase karkas (Aror, 1989). Penelitian selanjutnya oleh Hutabarat (2007) menyatakan bahwa pemberian kulit buah kopi fermentasi dengan Aspergilus niger taraf $10 \%$ masih dapat diberikan kepada Ayam buras, karena tidak menunjukkan perbedaan pada pertambahan berat badan, konsumsi ransum, dan konversi ransum.

\section{MATERI DAN METODE PENELITIAN}

Penelitian ini telah dilaksanakan pada tanggal 1 September - 14 Oktober 2014 (6 minggu) di kandang unggas jurusan Nutrisi dan Makanan Ternak Fakultas Peternakan Universitas Sam
Ratulangi Manado. Penelitian ini menggunakan 60 ekor broiler unsex strain Hubbard, umur 3 hari.

Ransum dasar yang digunakan dalam penelitian ini terdiri dari jagung kuning, bungkil kelapa, tepung limbah pengalengan ikan, tepung kedelai, minyak dan top mix. Limbah kulit kopi yang digunakan, diperoleh dari pabrik pembuat kopi bubuk di kota Kotamobagu, yang memproduksi kopi jenis Robusta. Komposisi zat-zat makanan dan energi metabolis bahan makanan penyusun ransum dasar dapat dilihat pada Tabel 1, sedangkan komposisi zat-zat makanan dan energi metabolis kulit kopi tercantum pada Tabel 2. Pada Tabel 3 tercantum komposisi bahan makanan ransum percobaan dan Tabel 4. Komposisi zat-zat makanan dan energi metabolis ransum percobaan.

Tabel 1. Komposisi Zat Makanan dan Energi Metabolis Bahan Makanan Penyusun Ransum

\begin{tabular}{lcccccc}
\hline Bahan Makanan & Protein & $\begin{array}{c}\text { Serat } \\
\text { Kasar }\end{array}$ & Lemak & $\begin{array}{c}\text { Energi } \\
\text { Metabolis }\end{array}$ & Ca & P \\
\hline Jagung $^{*}$ & 9,42 & 2,15 & 5,17 & $2.983,50$ & 0,22 & 0,60 \\
Kedelai $^{* * *}$ & 40,38 & 6,56 & 9,91 & 2.540 & 0.24 & 0.58 \\
Bungkil Kelapa $^{*}$ & 24,74 & 15,02 & 9,36 & $3.279,75$ & 0,11 & 0,47 \\
$\begin{array}{l}\text { Tepung Limbah } \\
\text { Pengalengan Ikan }\end{array}$ & & & & & & \\
Minyak $^{* *}$ & 58,52 & 2,95 & 13,90 & $3.851,8$ & 7,04 & 3,67 \\
Top Mix $^{*}$ & - & - & 100 & 8.812 & - & - \\
Sumber : $^{*}$ & - & - & - & - & 5,38 & 1,44 \\
${ }^{* *}$ & Hasil Analisis Bagau, 2013 & & & & \\
${ }^{* * *}$ & Hasil Analisis PT. Delta, 2013 & & & &
\end{tabular}


Tabel 2. Komposisi Zat Makanan dan Energi Metabolis Kulit Kopi dan Dedak Halus

\begin{tabular}{llc}
\hline Zat Nutrisi & $\begin{array}{c}\text { Kulit Kopi } \\
(\%)\end{array}$ & $\begin{array}{c}\text { Dedak Halus } \\
(\%)\end{array}$ \\
\hline Bahan kering $^{*}$ & 88,79 & 96,99 \\
Kadar Air $^{*}$ & 11,21 & 3,01 \\
Lemak Kasar $^{*}$ & 7,06 & 4,41 \\
Serat Kasar $^{*}$ & 20,02 & 23,37 \\
Protein $^{*}$ & 16,72 & 8,07 \\
Abu $^{*}$ & 6,61 & 21,50 \\
Beta-N $^{*}$ & 45,59 & 42,65 \\
Energi Bruto & 4.084 & 3.718 \\
Ca & $0,23^{* * *}$ & $0,22^{* * *}$ \\
$\mathrm{P}$ & $0,02^{* * *}$ & $0,95^{* *}$ \\
\hline Sumber ${ }^{*} \quad$ Hasil Analisis Bahan Kering Laboratorium Nutrisi Ternak Ruminansia dan
\end{tabular}
Kimia Makanan Ternak, Fakultas Peternakan Universitas Padjadjaran (2014) ** NRC, 1994

**** $\quad$ Ruswendi, 2011

Tabel 3. Komposisi Bahan Makanan Ransum Percobaan

\begin{tabular}{lcccc}
\hline Bahan Ransum & R0 & R1 & R2 & R3 \\
\hline Jagung & 45,50 & 45,50 & 45,50 & 45,50 \\
Tepung Kedele & 13 & 13 & 13 & 13 \\
Bungkil Kelapa & 5 & 5 & 5 & 5 \\
Tepung Limbah Pengalengan Ikan & 14 & 14 & 14 & 14 \\
Dedak Halus & 21 & 14 & 7 & 0 \\
Kulit Kopi & 0 & 7 & 14 & 21 \\
Top Mix & 0,5 & 0,5 & 0,5 & 0,5 \\
Minyak & 1 & 1 & 1 & 1 \\
\hline Total & 100 & 100 & 100 & 100 \\
\hline
\end{tabular}

Tabel 4. Komposisi Zat Makanan dan Energi Metabolis Ransum Percobaan

\begin{tabular}{lcccc}
\hline Zat-zat Makanan & R0 & R1 & R2 & R3 \\
\hline Protein $(\%)$ & 19,62 & 21,27 & 21,87 & 22,48 \\
Serat Kasar $(\%)$ & 7,90 & 7,67 & 7,43 & 7,20 \\
Lemak (\%) & 7,98 & 8,17 & 8,35 & 8,54 \\
Energi Metabolis (Kkal/kg) & $3.103,68$ & $3.124,17$ & $3.144,67$ & $3.165,16$ \\
Ca $(\%)$ & 1,20 & 1,20 & 1,20 & 1,20 \\
P $(\%)$ & 1,09 & 1,03 & 0,96 & 0,90 \\
\hline
\end{tabular}

Dihitung berdasarkan Tabel 1, Tabel 2 dan Tabel 3.

Kandang yang digunakan yakni 20 unit kandang batere. Setiap kandang dilengkapi dengan lampu pijar 60 watt, tempat makan dan minum yang terbuat dari plastik. Perlengkapan lain yang digunakan yaitu wadah untuk 
mencampur ransum, timbangan digital, kantong plastik penampung ransum perlakuan, koran bekas, ember dan pisau. Penelitian ini merupakan penelitian eksperimental dengan menggunakan Rancangan Acak Lengkap (Steel and Torrie, 1980) yang terdiri dari 4 perlakuan dan 5 ulangan. Variable yang diukur yaitu:

1. Persentase karkas (diperoleh dari hasil perbandingan antara berat karkas (gram) dengan berat hidup (gram) dikalikan 100\%).

2. Persentase lemak abdomen (diperoleh dari hasil perbandingan antara berat lemak abdomen (gram) dengan berat hidup (gram) dikalikan 100\%).

\section{HASIL DAN PEMBAHASAN}

Data Hasil Penelitian tentang pengaruh penggantian dedak halus dengan kulit kopi dalam ransum terhadap persentase karkas dan lemak abdomen disajikan pada Tabel 5 .

\section{Pengaruh Perlakuan Terhadap Persentase Karkas}

Hasil penelitian menunjukkan bahwa rataan persentase karkas berkisar antara 67.41-72.77\% (Tabel 5). Persentase yang diperoleh berdasarkan hasil timbangan dalam bentuk "Ready To Cook" (tubuh ayam tanpa kepala, kaki, jeroan kecuali hati, rempela dan jantung). Menurut North (1984) persentase karkas "Ready To Cook" berkisar 70-77\% dari berat hidup, penelitian ini masih dalam kisaran tersebut, kecuali untuk persentase karkas pada R3. Hasil analisis keragaman menunjukkan bahwa perlakuan memberikan pengaruh berbeda sangat nyata $(\mathrm{P}<0.01)$ terhadap persentase karkas. Hasil Uji Lanjut menggunakan Uji BNJ menunjukkan bahwa tidak ada perbedaan yang nyata pada persentase karkas antara R0 $(72,77 \%), \quad$ R1 $(71,96)$ dan R2 $(71,45 \%)$, tetapi pada R3 (67,41\%) persentase karkas nyata lebih rendah dibanding R0, R1 dan R2.

Tabel 5. Rataan Persentase Karkas dan Lemak Abdomen Masing-masing Perlakuan

\begin{tabular}{|c|c|c|c|c|}
\hline \multirow{2}{*}{ Variabel } & \multicolumn{4}{|c|}{ Perlakuan } \\
\hline & R0 & $\mathrm{R} 1$ & $\mathrm{R} 2$ & R3 \\
\hline Karkas (\%) & $72.77^{\mathrm{a}}$ & $71.96^{\mathrm{a}}$ & $71.45^{\mathrm{a}}$ & $67.41^{b}$ \\
\hline Lemak (\%) & $1.78^{\mathrm{a}}$ & $1.7^{\mathrm{a}}$ & $1.15^{\mathrm{b}}$ & $0.88^{\mathrm{c}}$ \\
\hline
\end{tabular}


Penggantian dedak halus dengan kulit buah kopi sebanyak 14\% memberikan persentase karkas yang sama dengan R0 (tanpa penggantian kulit buah kopi), sedangkan penggantian dedak halus dengan kulit kopi sebesar $21 \%$ terjadi penurunan persentase karkas.

Menurunnya persentase karkas seiring dengan bertambahnya jumlah pemberian kulit kopi diduga karena zat antinutrisi yang terkandung dalam kulit kopi yakni tanin dan kafein yang dapat menghambat pertumbuhan (Molina, 1974 dan Brahman, 1979 dalam Aror, 1989). Tandi (2010) mengemukakan Tanin yang masuk ke dalam saluran pencernaan akan terikat dengan protein sehingga sulit dicerna oleh enzim protease mengakibatkan asam-asam amino sedikit terbentuk dan akan mempengaruhi pertumbuhan. Begitu pula pati yang masuk ke dalam saluran pencernaan akan terikat dengan tanin sehingga sulit dicerna oleh enzim amilase menjadi glukosa. Akibatnya produksi energi berkurang yang akan mempengaruhi metabolisme zat-zat makanan dalam tubuh. Besarnya persentase karkas ditentukan oleh jumlah energi yang diperoleh ternak dari zat-zat makanan yang terkandung dalam bahan makanan.

\section{Pengaruh Perlakuan Terhadap Persentase Lemak Abdomen}

Rataan persentase lemak abdomen dari masing-masing perlakuan selama penelitian berkisar antara 0.88-1.78\% (Tabel 5). Menurut North (1984), persentase lemak abdomen untuk broiler umur 6-8 minggu maksimal $3.30 \%$. Persentase lemak abdomen dalam penelitian ini masih dibawah batas maksimal persentase lemak yang disarankan North (1984). Hasil analisis keragaman menunjukkan bahwa perlakuan memberikan pengaruh berbeda sangat nyata terhadap persentase lemak abdomen. Hasil Uji BNJ menunjukkan perlakuan tanpa kulit buah kopi $(1,78 \%)$ berbeda tidak nyata $(\mathrm{P}>0.05)$ dibandingkan dengan penggantian $7 \%(1,7 \%)$, tetapi berbeda nyata lebih tinggi $(\mathrm{P}<0.05)$ dibanding penggantian $14 \%(1,15 \%)$, dan terhadap penggantian $21 \%(0,88 \%)$ berbeda sangat nyata lebih tinggi $(\mathrm{P}<0.01)$.

Hasil Uji BNJ, memberikan indikasi bahwa semakin tinggi level penggunaan kulit buah kopi dalam ransum akan menurunkan persentase lemak abdomen pada broiler. 
Rendahnya persentase lemak abdomen diduga disebabkan oleh adanya zat anti nutrisi dalam kulit kopi yaitu kafein dan tanin. Molina dkk,(1974) dan Brahman (1979) dalam Aror (1989) menyatakan bahwa kafein dapat menekan pertumbuhan. Tandi (2010) mengemukakan tanin dapat mengikat protein membentuk ikatan kompleks protein tanin sehingga protein tersebut sukar dicerna oleh enzim protease. Tanin juga mempengaruhi metabolisme karbohidrat dengan mengikat pati sehingga sukar dicerna oleh enzim amilase (Goldstein dan Swain, 1965 dan Leinmuller et al., 1991, dalam Tandi 2010). Terhambatnya proses metabolisme oleh tanin mengakibatkan zat-zat makanan yang dicerna sedikit sehingga tidak ada kelebihan energi yang dapat disimpan dalam jaringan lemak. Tandi (1993) dalam Tandi (2010) mengatakan bahwa akibat dari pengikatan tanin terhadap pati pada ternak babi menyebabkan pati kurang tercerna, sehingga produksi energi atau lemak berkurang dan mengakibatkan tebal lemak punggung berkurang. Semua perlakuan yang diberikan menghasilkan persentase lemak abdomen setengah dari standar yang dikemukakan North (1984). Pada perlakuan R2 (14\% kulit kopi) penurunan persentase lemak abdomen sangat nyata terlihat. Hal ini juga diduga disebabkan kafein menghambat enzim- enzim perncernaan sehingga pencernaan tidak berjalan dengan baik. Disamping itu serat kasar dalam kulit kopi mengandung selulosa dan lignin dalam jumlah besar, yaitu selulosa 20,22 \% dan lignin 24,67\%. Selulosa dan lignin merupakan serat kasar yang sulit dicerna oleh tubuh (Amrullah, 2004).

\section{KESIMPULAN}

Berdasarkan hasil penelitian ini dapat disimpulkan bahwa penggantian dedak halus dengan kulit kopi sebanyak $14 \%$ memberikan nilai persentase karkas dan lemak abdomen yang terbaik.

\section{DAFTAR PUSTAKA}

Amrullah, I. K. 2004. Nutrisi Ayam Broiler. Cetakan ketiga. Lembaga satu Gunungbudi. Bogor.

Anggorodi, R. 1985. Ilmu Makanan Ternak Unggas. Universitas Indonesia. Jakarta.

Aror, M. 1989. Kulit Kopi Sebagai Pengganti Dedak Halus DAlam Ransum Ayam Pedaging Jantan Periode Finisher. Skripsi. Fakultas Peternakan. UNSRAT Manado.

Hutabarat, H. 2007. Pemanfaatan Kulit Buah Kopi Terfermentasi Terhadap Performans dan Kualitas Karkas Ayam Buras. Pusat Kajian Peternakan, Perikanan, Sumberdaya Pesisir dan Laut. Fakultas Peternakan. Universitas HKBP Nommensen. Medan. 
Kementerian Perindustrian RI, 2013. Produsi Kopi Nusantara Ketiga Terbesar di Dunia. Siaran Pers. Jakarta.

North, M.O. 1984. Commercial Chicken Production Manual. The Avi Publishing Company Inc. Wesport, Connecticut, USA.

NRC. 1994. Nutrient Requirements of Poultry. Ninth Revised Edition. National Academy Press. Washington. USA.

Ruswendi, 2011. Teknologi Pakan Berkualitas untuk Sapi Potong. Balai Pengkajian Teknologi Pertanian Bengkulu email: bptpbengkulu@yahoo.com

Sembor, S.M., 1989. Pengaruh Berbagai umber Ransum Berserat dalam Ransum Terhadap Beberapa Karakteristik dan Presentase
Karkas Ayam Pedaging Jantan. Tesis. Fakultas Peternakan. Universitas Sam Ratulangi. Manado.

Steel, R. G. D. \& J. H. Torrie.1994. Prinsip Dan Prosedur Statistik. Suatu Pendekatan Biometrik. Terjemahan: B. Sumantri. Gramedia. Jakarta.

Tandi, E. J. 2010. Pengaruh Tanin Terhadap Aktivitas Protease. Seminal Nasional Teknologi Peternakan dan Veteriner. Fakultas Peternakan. Universitas Hasanuddin. Makassar. Hal: 567570.

Wahyu, J., 2004. Ilmu Nutrisi Unggas. Cetakan Kelima. Gadjah Mada University Press. Yogyakarta. 